\title{
New method for rearing Spodoptera frugiperda in laboratory shows that larval cannibalism is not obligatory
}

\author{
Cherre Sade Bezerra Da Silva ${ }^{1,2}$ \& José Roberto Postali Parra ${ }^{1}$
}

\begin{abstract}
'Laboratório de Biologia de Insetos, Departamento de Entomologia e Acarologia, Escola Superior de Agricultura "Luiz de Queiroz", Universidade de São Paulo. Avenida Pádua Dias, 11, 13418-900 Piracicaba-SP, Brazil, entomologista@gmail.com, jrpparra@usp.br ${ }^{2}$ Corresponding author: Walter Leal's Laboratory, Surge I, UC Davis, Department of Molecular and Cellular Biology, 95.616, Davis, CA, USA.
\end{abstract}

\begin{abstract}
New method for rearing Spodoptera frugiperda in laboratory shows that larval cannibalism is not obligatory. Here we show, for the first time, that larvae of the fall armyworm (FAW), Spodoptera frugiperda (Lepidoptera, Noctuidae), can be successfully reared in a cohort-based manner with virtually no cannibalism. FAW larvae were reared since the second instar to pupation in rectangular plastic containers containing 40 individuals with a surprisingly $c a .90 \%$ larval survivorship. Adult females from the cohort-based method showed fecundity similar to that already reported on literature for larvae reared individually, and fertility higher than $99 \%$, with the advantage of combining economy of time, space and material resources. These findings suggest that the factors affecting cannibalism of FAW larvae in laboratory rearings need to be reevaluated, whilst the new technique also show potential to increase the efficiency of both small and mass FAW rearings.
\end{abstract}

KEYWORDS. Artificial diet; cannibalistic behavior; fall armyworm; mass production; rearing technique.

The fall armyworm (FAW), Spodoptera frugiperda (Smith, 1797) (Lepidoptera, Noctuidae), is a key pest of corn in Brazil as well as the greater Americas. For decades, researchers around the world have reared this species in laboratories for the purpose of conducting studies on its biology, behavior and also for using it as a host of natural enemies. Despite the several artificial diets suitable for FAW, its larval cannibalistic behavior is considered a challenge for most rearers. Cannibalism has been documented in field (Sarmento et al. 2002; Farias et al. 2001; Chapman et al. 2000; Silva 1999) and indoor (Zennerde-Polania et al. 2009; Goussain et al. 2002; Chapman et al. 1999a,b; Mihm 1983;) conditions, encouraging one to rear the larvae in individual vials as a way to decrease the preimaginal mortality (Vilarinho et al. 2011; Busato et al. 2006; Chapman et al. 2000; Perkins 1979; Burton \& Perkins 1972; Burton \& Cox 1966). Although being a well-diffused method, to culture larvae of FAW individually is not practical and may be very time- and resource-consuming even in small rearings, suggesting the need to develop a more efficient technique. Here we describe a cohort-based method for rearing larvae of $S$. frugiperda and show, for the first time, that cannibalism is not necessarily an issue when FAW larvae are reared in cohorts instead of individually.

\section{MATERIAL AND METHODS}

In mid-October 2010 (early spring), corn plants ( $c a .30$ days after emergence) were collected from a plot $\left(22^{\circ} 42^{\prime}\right.$ $\left.11.5^{\prime \prime} \mathrm{S}, 47^{\circ} 38^{\prime} 1.1^{\prime \prime} \mathrm{W}\right)$ infested with fall armyworm. In laboratory, caterpillars were picked from leaves and stem of plants and then reared individually on the artificial diet proposed by Greene et al. (1976), according to the methods of Parra (2001) $\left(24 \pm 1^{\circ} \mathrm{C}, 70 \% \mathrm{RH}, 14 \mathrm{~L}: 10 \mathrm{D}\right.$ photoperiod). When molted to pupae, the insects were collected and placed in PVC cages ( $21 \mathrm{~cm}$ height x $10 \mathrm{~cm}$ diameter) until adult emergence, and then maintained as described by Parra (2001). Egg patches deposited by these adults were inserted in glass tubes $(2 \times 8 \mathrm{~cm})$ and, as soon the caterpillars hatched, they were transferred to disposable plastic cups $(200 \mathrm{~mL})$ containing the artificial diet. When achieved the second-instar (ca. 4-5 day-old), forty caterpillars were introduced in rectangular containers ( $4 \mathrm{~cm}$ height $\times 15 \mathrm{~cm}$ width $\mathrm{x} 21 \mathrm{~cm}$ length) filled with $200 \mathrm{~mL}$ of the artificial diet (Figs. 1,2). The containers were stacked closing each other and plastic lids were used to close the containers in the top of the piles (Fig. 3). In order to avoid excess of moisture on the container surface (Fig. 4) and the development of entomopathogenic microorganisms, we promoted a reduction of $11 \%$ of the water content proposed by Greene et al. (1976). After 14 days the pupae were collected and introduced in PVC cages as before, when the process was repeated, as already described, for several generations. In $\mathrm{F}_{12}$, the larval survivorship rate, and the fecundity and fertility of adult female were measured. Larval survivorship in each container $(\mathrm{N}=44)$ was evaluated by the formula: Number of healthy pupae/40*100. For measuring the fecundity, 20 FAW couples were introduced, as soon they emerged, in $20 \mathrm{PVC}$ cages $(10 \mathrm{~cm}$ height $\mathrm{x} 10 \mathrm{~cm}$ diameter $)$, which were maintained in the shelves of a climatic chamber (24 $\pm 1{ }^{\circ} \mathrm{C}, 70 \% \mathrm{RH}, 14 \mathrm{~L}: 10 \mathrm{D}$ photoperiod). Egg patches were collected and counted daily. For evaluation of fertility, after egg counting, paper containing egg masses were maintained in the shelves of a second climatic chamber $\left(24 \pm 1^{\circ} \mathrm{C}\right.$, 


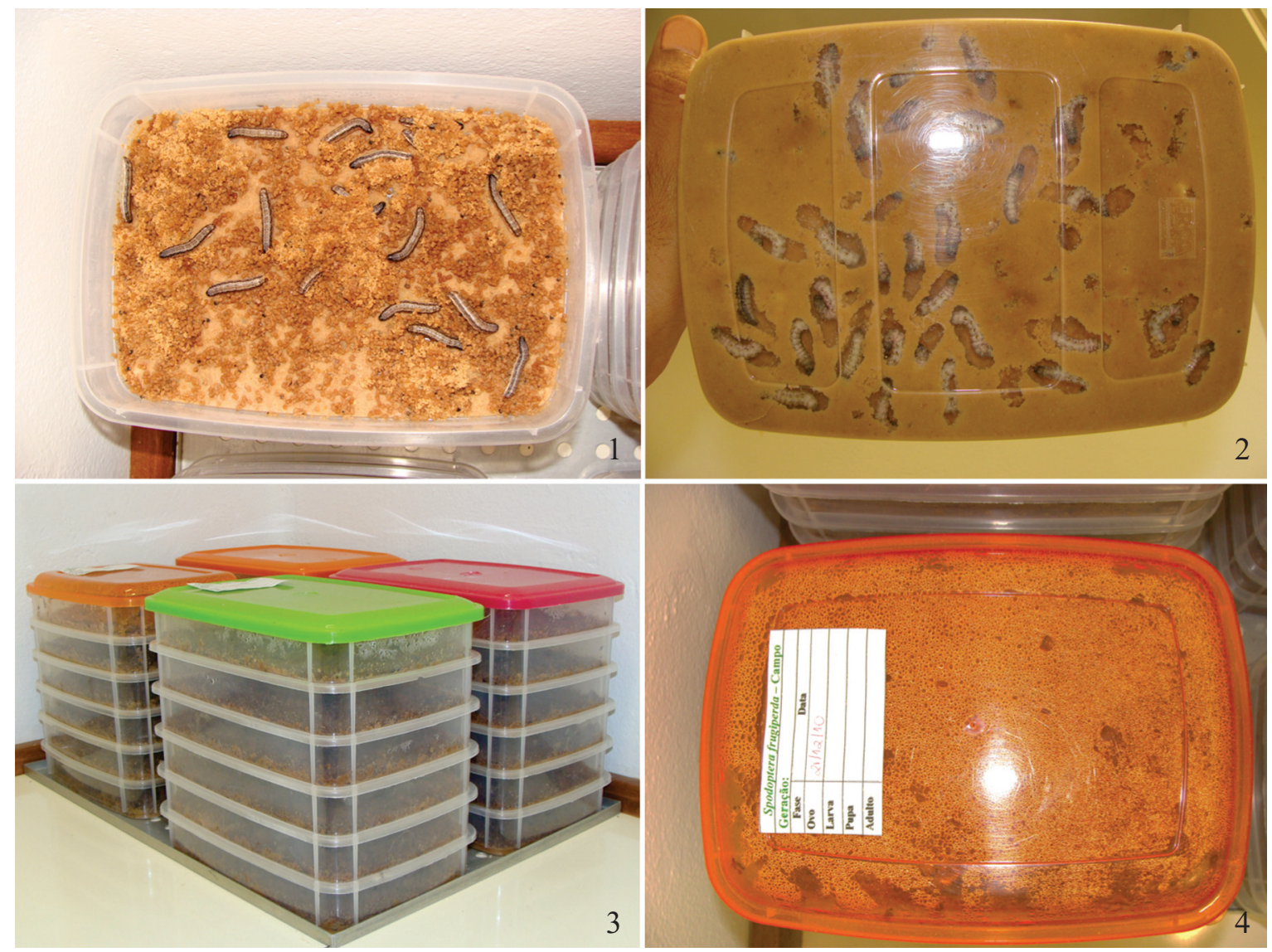

Figs. 1-4. Cohort-based method for rearing larvae of Spodoptera frugiperda. 1. Top view of the plastic container (4 x $15 \times 21 \mathrm{~cm})$ with artificial diet (light brown) (Greene et al. 1976), frass (dark brown) and fifth instar larvae. 2. Bottom view of the container showing prepupae into their molt chambers. 3. Containers stacked aiming at saving space. 4. Water drops condensed on the inner surface of the container lid (this problem was addressed by reducing in $11 \%$ the amount of water suggested by Greene et al. (1976)).

70\% RH, 14L:10D photoperiod) and the non-hatched eggs were counted after four days. To avoid an eventual cannibalism of newly-hatched larvae on non-hatched eggs we collected and killed the larvae twice a day.

\section{RESULTS AND DISCUSSION}

A mean of $36.3 \pm 0.4$ out of the 40 larvae of $S$. frugiperda were able to successfully develop and reach the pupal stage in each rearing container, which corresponded to $90.75 \pm$ $0.9 \%$ of larval survivorship. Chapman et al. (1999a,b) found that cannibalistic behavior occurs in a frequency of about 43 to $80 \%$ when larvae are reared in groups and, in a further study, Chapman et al. (2000) reared FAW larvae individually. In Brazil, Nalim (1991) observed high rates of cannibalism when FAW larvae were fed on corn leaves, in contrast with the significantly lower rates found on artificial diet. The author explained these results suggesting that the cannibalism might be a way to get a meal of high nutritional value in an environment where only low nutritional value food, like the corn leaves, is available. Despite that, Brazilian researchers have reported exclusively the individually-cultured larvae when rearing FAW, always justifying it with the occurrence of larval cannibalism (e.g. Goulart et al. 2011; Vilarinho et al. 2011; Bueno et al. 2010, 2008).

Our study showed that cannibalism is not a critical factor of mortality for larvae of FAW in laboratory rearings. Hence, individualizing the insects is not mandatory to avoid larval and pupal mortality due to such negative interaction. Our results and the discrepancies between the cannibalism rates reported by different authors suggest that the genetics of the FAW or even differences in the rearing methods play a role on the cannibalistic behavior. Thus, before the establishment of a FAW rearing, preliminary tests should be taken in order to check out its cannibalism rate and to adjust the most efficient method of rearing.

Each female of $S$. frugiperda was able to lay an average of 1,832.30 $\pm 100.11 \mathrm{eggs}$ along their lifespan, whose 99.10 $\pm 0,13 \%$ were fertile. Busato et al. (2006), rearing a corn population of FAW also from Brazil in individualized vials and on the same substrate we used (Greene et al. 1976), found a fecundity of ca. 1,874 eggs/female, which is virtually the same reported by us. Such results point that the cohort-based rearing method here presented is not only efficient at ensuring a high larval survivorship, but is also suitable for promoting a female fecundity similar to the widespread method of culturing larvae individually. 
The implications of a cohort-based method of FAW on the feasibility of its rearing can be easily measured. For example, four plastic containers can carry 160 larvae of $S$. frugiperda in an area of $1,260 \mathrm{~cm}^{2}(42 \times 30 \mathrm{~cm})$. If we use exactly the same area to apply the individual method based on plastic cups $(4 \times 5 \mathrm{~cm})$ (Vilarinho et al. 2006), we could rear roughly 40 larvae, which is only one-quarter of the cohort-based method here presented. Moreover, we should mention the economy in time promoted by the latter method. Although we did not take measurements, it is not difficult to have in mind that the time spent distributing cups in a tray and then filling them, one by one with artificial diet, one single larva, and a lid, will take substantially more time than doing the same steps for a group of 40 larvae at once. Indeed, considering that cannibalism was not shown to be a problem for FAW rearing, even larger containers might be used according to the availability of space. Finally, considering the amount of artificial diet often not consumed (out of the $200 \mathrm{~mL}$ available) by the larvae until the end of their development (Figs. 1, 2), new studies need to be performed in order to test the effects of decreasing the amount of diet offered, and of increasing the density of larvae per container.

A feasible method for rearing larvae of $S$. frugiperda in laboratory has been long demanded. Here were described a suitable technique for such need showing, for the first time, that the FAW larvae can be successfully reared under a cohortbased method with no negative effects of cannibalism on larval survivorship nor on fecundity and fertility of the adult females. These findings suggest that the factors affecting cannibalism of FAW larvae in laboratory rearings need to be reevaluated, whilst the new technique also show potential to increase the efficiency of both small and mass FAW rearings.

\section{ACKNOWLEDGEMENTS}

We are grateful to Mariana Graciano Zério for collaborating with the insect rearing; and to Alyssa De La Rosa, for the English revision. This work was supported by Fundação de Amparo à Pesquisa do Estado de São Paulo - FAPESP (process 2007/07054-8).

\section{REFERENCES}

Bueno, R.C.O.F.; Bueno, A.F., Parra, J.R.P., Vieira, S.S. \& Oliveira, L.J. 2010. Biological characteristics and parasitism capacity of Trichogramma pretiosum Riley (Hymenoptera, Trichogrammatidae) on eggs of Spodoptera frugiperda (J. E. Smith) (Lepidoptera, Noctuidae). Revista Brasileira de Entomologia 54: 322-327.

Bueno, R.C.O.F., Carneiro, T.R., Pratissoli, D., Bueno, A.F. \& Fernandes, O.A. 2008. Biology and thermal requirements of Telenomus remus reared on fall armyworm Spodoptera frugiperda eggs. Ciência Rural 38: $1-6$.
Burton, R.L. \& Cox, H.C. 1966. An automated packing machine for lepidopterous larvae. Journal of Economic Entomology 59: 907-909.

Burton, R.L. \& Perkins, W.D. 1972. WSB, a new laboratory diet for the corn earworm and the fall armyworm. Journal of Economic Entomology 65: 385-386.

Busato, G.R., Garcia, M.S., Loeck, A.E., Zart, Nunes, M.A.M., Bernardi; O. \& Andersson, F.S. 2006. Adequação de uma dieta artificial para os biótipos "milho" e "arroz" de Spodoptera frugiperda (Lepidoptera: Noctuidae). Bragantia 65: 317-323.

Chapman, J.W., Williams, T., Escribano, A., Caballero, P., Cave, R.D. \& Goulson, D. 1999a. Age-related cannibalism and horizontal transmission of a nuclear polyhedrosis virus in larval Spodoptera frugiperda. Ecological Entomology 24: 268-275.

Chapman, J.W., Williams, T., Escribano, A., Caballero, P., Cave, R.D. \& Goulson, D. 1999b. Fitness consequences of cannibalism in the fall armyworm, Spodoptera frugiperda. Behavioral Ecology 10: 298-303.

Chapman, J.W., Williams, T., Martinez, A.M., Cisneros, J., Caballero, P. Cave, R.D. \& Goulson, D. 2000. Does cannibalism in Spodoptera frugiperda (Lepidoptera: Noctuidae) reduce the risk of predation? Behavioral Ecology and Sociobiology 48: 321-327.

Farias, P.R.S., Barbosa, J.C. \& Busoli, A.C. 2001. Amostragem sequencial com base na lei de Taylor para levantamento de Spodoptera frugiperda na cultura do milho. Scientia Agricola 58: 395-399.

Goulart, M.M.P., Bueno, A.F., Bueno, R.C.O.F.\& Diniz, A.F. 2011. Host preference of the egg parasitoids Telenomus remus and Trichogramma pretiosum in laboratory. Revista Brasileira de Entomologia 55: 129-133.

Goussain, M.M., Moraes, J.C., Carvalho, J.G., Nogueira N.L., \& Rossi, M.L. 2002. Efeito da aplicação de silício em plantas de milho no desenvolvimento biológico da lagarta-do-cartucho Spodoptera frugiperda (J.E.Smith) (Lepidoptera: Noctuidae). Neotropical Entomology 31: 305-310.

Greene, G.L., Leppla, N.C. \& Dickerson, W.A. 1976. Velvetbean caterpillar: A rearing procedure and artificial medium. Journal of Economic Entomology 69: 487-488.

Mihm, J.A. 1983. Efficient mass-rearing and infestation techniques to screen for host plant resistance to fall armyworm, Spodoptera frugiperda. EI Satan, Centro Internacional de Mejoramiento de Maiz y Trigo CIMMYT, $16 \mathrm{p}$.

Nalim, D.M. 1991. Biologia, nutrição quantitativa e controle de qualidade de populações de Spodoptera frugiperda (J. E. Smith, 1797) (Lepidoptera: Noctuidae) em duas dietas artificiais. Ph. D. dissertation. Escola Superior de Agricultura "Luiz de Queiroz" - Universidade de São Paulo, 150 p.

Parra, J.R.P. 2001. Técnicas de criação de insetos para programas de controle biológico. Piracicaba, ESALQ/FEALQ, 137 p.

Perkins, W.D. 1979. Laboratory rearing of the fall armyworm. Florida Entomologist 62: 87-91.

Sarmento, R.A., Aguiar, R.W.S., Aguiar, R.A.S.S., Vieira, S.M.J., Oliveira, H.G. \& Holtz, A.M. 2002. Revisão da biologia, ocorrência e controle de Spodoptera frugiperda (Lepidoptera, Noctuidae) em milho no Brasil. Bioscience Journal 18: 41-48.

Silva, M.T.B. 1999. Fatores que afetam a eficiência de inseticidas sobre Spodoptera frugiperda Smith em milho. Ciência Rural 29: 383-388.

Vilarinho, E.C., Fernandes, O.A., Hunt, T.E. \& Caixeta, D.F. 2011 Movement of Spodoptera frugiperda adults (Lepidoptera: Noctuidae) in maize in Brazil. Florida Entomologist 94: 480-488.

Vilarinho, E.C., Fernandes, O.A., Omoto, C. \& Hunt, T.E. 2006. Oil-soluble dyes for marking Spodoptera frugiperda (Lepidoptera: Noctuidae). Journal of Economic Entomology 99: 2110-2115.

Zenner de Polania, I.,Arevalo Maldonado, H.A., Mejia Cruz, R., \& Diaz Sánchez, J.L. 2009. Spodoptera frugiperda: respuesta de distintas poblaciones a la toxina Cry1Ab. Revista Colombiana de Entomología 35: 34-41. 